\title{
Description of deutonymphs of Kamertonia polonica Gabryś, 2000 (Acari: Actinotrichida: Erythraeidae)
}

\author{
ELŻBIETA ROLAND and GRZEGORZ GABRYŚ \\ Department of Zoology, Faculty of Biological Sciences, University of Zielona Góra, \\ Szafrana 1, 65-516 Zielona Góra, Poland \\ Corresponding authors: e.roland@wnb.uz.zgora.pl,g.gabrys@wnb.uz.zgora.pl
}

(Received on 31 January 2012; Accepted on 29 November 2012)

\begin{abstract}
A detailed description of deutonymphs of Kamertonia polonica Gabryś, 2000 is provided for the first time. Their general appearance is similar to adults and the slight differences are quantitative. The distribution of $K$. polonica is discussed.
\end{abstract}

Keywords: Parasitengona, Erythraeinae, deutonymph, Finland

\section{INTRODUCTION}

The subfamily Erythraeinae comprises 17 nominate genera, known from postlarval instars. Two groups of genera can be distinguished: the so-called "conalae" group and the "conalae-less" one. Hitherto, 10 genera of "conalae-less" Erythraeinae have been described, including monotypic Kamertonia Gabryś, 2000. Kamertonia polonica Gabryś, 2000 has been recorded in only 3 localities, on the Polish and Finnish shores of the Baltic Sea (GABRYŚ, 2000; GABRYś et al. 2009). So far, only females of this species have been described (GABRYŚ 2000). GABRYś et al. (2009) reported the finding of $K$. polonica deutonymphs in the course of research on Erythraeoidea of Finland. However, neither the detailed description nor precise data on their occurrence were given then. The aim of the present study was to analyse the morphological structure of $19 \mathrm{~K}$. polonica deutonymphs collected from the only locality in Finland.

\section{MATERIAL AND METHODS}

Material used in this study derives from Finland and has been provided by the Zoological Museum in Turku (MZUT). The specimens, originally preserved in isopropyl alcohol, were macerated using Nesbitt's fluid, mounted in Faure's medium 
(Krantz 1978; KrantZ and Walter 2009), and used for morphology-based diagnosis. The observations were carried out using microscopes Olympus BX51 and BX52 with phase and differential interference contrast (DIC). The specimens were determined using comparative material from the junior author's collection and available literature. The microphotographs were taken with Olympus Camedia C-3030 ZOOM digital camera paired with Olympus DP-Soft 3.1 PC software.

In the description, structural, metric, and meristic characters were used. For the measurements, 6 best-preserved specimens were selected. Morphological structures were measured using a microscope with phase contrast equipped with measurement optics. Morphological terminology follows Southcotт (1961), Welbourn and Young (1987), Gabryś (1992, 1999, 2000), and MĄKol (2005) and Roland (2008).

\section{RESULTS}

Erythraeidae Robineau-Desvoidy, 1828

Erythraeinae Robineau-Desvoidy, 1828

Kamertonia Gabryś, 2000

Kamertonia polonica Gabryś, 2000

Terra typica: Poland

\section{Diagnosis}

Female. Medium size, as compared to other Erythraeinae; body oval, green with metallic lustre in lifetime. Idiosoma covered with characteristic, bifurcate, uniform (in shape and length) setae, which resemble a tuning fork, crista metopica short, with relatively weakly sclerotized anterior part of anterior sensillary area; palps narrow, without conalae on palptibia and without crescent-shaped cavity at proximal-ventral side of palpgenu; vestigala on tibia I cylindrical (equal in width) (GABRYś 2000).

Male. Not known

Deutonymph. General appearance similar to adult. Any differences only quantitative. Genital opening rudimentary, still closed.

Larva. Not known

\section{Description of deutonymphs}

Body oval. Mean length $770.6 \mu \mathrm{m}$ (Table 1). Gnathosoma: chelicerae daggerlike, retractable into idiosoma. Palps relatively thin, all segments elongated, with sparse setation. Crescent cavity not present on palpgenu. Palptarsus relatively long, club-like, with solenidia. Claw on palptibia prominent, with a clear tooth-like projection at base. No conalae and semiconalae on palptibia and palpgenu.

Aspidosoma: crista metopica relatively short, $120-179 \mu \mathrm{m}$ in length. Anterior sensillary area weakly sclerotized, with a pair of rigid, relatively thick sensillary setae (their distal half covered with hairs, Fig. 1), and 5-6 nonsensillary setae forked at base, like dorsal opisthosomal setae. Opisthosomal setae dagger-like, covered with hairs on nearly whole length (Fig. 1). Nonsensillary setae shorter than anterior and posterior sensillary setae. Posterior sensillary area oval, not entirely sclerotized, with 
Table 1. Standard measurements of Kamertonia polonica deutonymphs from Finland

\begin{tabular}{|c|c|c|c|c|c|}
\hline Character & $\begin{array}{c}\text { No. of } \\
\text { specimens }\end{array}$ & $\begin{array}{c}\text { Mean } \\
(\mu \mathrm{m})\end{array}$ & $\underset{(\mu \mathrm{m})}{\operatorname{Minimum}}$ & $\begin{array}{l}\text { Maximum } \\
(\mu \mathrm{m})\end{array}$ & $\begin{array}{c}\mathrm{SD} \\
(\mu \mathrm{m})\end{array}$ \\
\hline LB & 6 & 770.6 & 622.4 & 1075.0 & 155.37 \\
\hline WB & 6 & 533.5 & 444.6 & 675.0 & 77.46 \\
\hline ASRo & 6 & 139.5 & 121.5 & 153.4 & 11.23 \\
\hline PSG & 5 & 239.0 & 200.9 & 281.3 & 36.13 \\
\hline GAn & 5 & 106.6 & 90.0 & 138.9 & 18.79 \\
\hline GOp & 5 & 232.1 & 171.8 & 285.3 & 42.56 \\
\hline AnOp & 5 & 84.8 & 44.6 & 106.6 & 25.81 \\
\hline $\mathrm{mdS}$ & 6 & 20.2 & 19.8 & 22.0 & 0.90 \\
\hline pdS & 6 & 27.9 & 27.3 & 29.0 & 0.88 \\
\hline $\mathrm{mvS}$ & 6 & 25.4 & 24.8 & 27.3 & 1.04 \\
\hline pvS & 6 & 29.6 & 27.3 & 32.2 & 1.97 \\
\hline $\mathrm{AL}(\mathrm{n})$ & 6 & 5.3 & 5.0 & 6.0 & 0.52 \\
\hline $\mathrm{AL}$ & 6 & 54.5 & 52.1 & 59.0 & 2.96 \\
\hline ASE & 6 & 60.0 & 54.6 & 65.0 & 3.56 \\
\hline PSE & 6 & 64.2 & 59.5 & 70.0 & 4.15 \\
\hline CML & 6 & 161.0 & 119.5 & 178.9 & 21.07 \\
\hline CMW & 6 & 4.8 & 4.0 & 5.0 & 0.40 \\
\hline ASAL & 6 & 40.8 & 38.0 & 44.0 & 2.23 \\
\hline ASAW & 6 & 36.3 & 32.0 & 41.0 & 3.01 \\
\hline PSAL & 6 & 46.8 & 42.0 & 52.0 & 4.16 \\
\hline PSAW & 6 & 26.8 & 24.8 & 29.8 & 1.71 \\
\hline ISD & 6 & 126.0 & 119.0 & 138.9 & 7.26 \\
\hline $\mathrm{SBa}$ & 6 & 15.1 & 14.9 & 16.0 & 0.45 \\
\hline SBp & 6 & 14.9 & 14.9 & 15.0 & 0.04 \\
\hline $\mathrm{ASBa}$ & 6 & 21.8 & 20.0 & 25.0 & 2.23 \\
\hline PSBp & 6 & 20.5 & 17.4 & 23.0 & 2.15 \\
\hline OCM & 6 & 108.6 & 81.8 & 138.6 & 20.59 \\
\hline OAS & 5 & 85.2 & 76.9 & 89.3 & 5.71 \\
\hline OPS & 5 & 40.28 & 30.0 & 49.6 & 9.28 \\
\hline $\mathrm{aO}$ & 6 & 9.8 & 9.0 & 11.0 & 0.98 \\
\hline $\mathrm{O}$ & 6 & 38.8 & 38.0 & 39.7 & 0.66 \\
\hline pO & 6 & 8.1 & 7.0 & 9.0 & 0.82 \\
\hline $\mathrm{O}-\mathrm{O}$ & 6 & 220.2 & 181.0 & 282.1 & 37.27 \\
\hline ExGL & 6 & 15.6 & 10.0 & 20.0 & 3.83 \\
\hline ExGLaL & 6 & 23.8 & 19.8 & 27.0 & 2.49 \\
\hline $\mathrm{AnL}$ & 6 & 40.9 & 37.2 & 42.2 & 2.07 \\
\hline $\operatorname{AnLa}(n)$ & 6 & 4.7 & 4 & 5 & 0.52 \\
\hline
\end{tabular}


Symbols denote the length of the structure, unless stated otherwise: $\mathrm{SD}=$ standard deviation; $\mathrm{LB}=$ body length (from anterior edge of aspidosoma to posterior edge of opisthosoma); WB = body width; ASRo = perpendicular distance between line of centres of anterior sensilla bases and anterior edge of rostrum, including fan (Fn), excluding chelicerae; PSG = perpendicular distance between line of centres of posterior sensilla bases and anterior edge of external genital sclerite; GAn = distance between posterior edge of external genital sclerite and anterior edge of external anal sclerite; GOp = distance between posterior edge of external genital sclerite and posterior edge of opisthosoma; AnOp = distance between posterior edge of external anal sclerite and posterior edge of opisthosoma; $\mathrm{mdS}=$ middorsal opisthosomal setae; $\mathrm{pdS}=$ postdorsal opisthosomal setae; $\mathrm{mvS}=$ midventral opisthosomal setae; $\mathrm{pvS}=$ postventral opisthosomal setae; $\mathrm{AL}(\mathrm{n})=$ number of nonsensillary setae on anterior sensillary area; $\mathrm{AL}=$ nonsensillary setae; $\mathrm{ASE}=$ anterior sensillae; $\mathrm{PSE}=$ posterior sensillae; $\mathrm{CML}=$ total length of crista metopica (including anterior process, sensillary area, and posterior process); CMW = width of crista metopica measured at level of rod; ASAL = length of anterior sensillary area of crista metopica excluding anterior process; ASAW = width of anterior sensillary area of crista metopica; PSAL = length of posterior sensillary area of crista metopica excluding posterior process; PSAW = width of posterior sensillary area of crista metopica; ISD = perpendicular distance between lines of centres of anterior sensilla bases and posterior sensilla bases; $\mathrm{SBa}=$ distance between centres of anterior sensilla bases; $\mathrm{SBp}=$ distance between centres of posterior sensilla bases; $\mathrm{ASBa}=$ perpendicular distance between line of centres of anterior sensilla bases and anterior edge of crista metopica excluding anterior process; PSBp = perpendicular distance between line of centres of posterior sensilla bases and posterior edge of crista metopica excluding posterior process; OCM = perpendicular distance between crista metopica axis and eye centre; OAS = distance between eye centre and midpoint between anterior sensilla bases measured in the median plane; OPS = distance between eye centre and midpoint between posterior sensilla bases measured in the median plane; $\mathrm{Oa}=$ anterior lens; $\mathrm{O}=$ eye; $\mathrm{Op}=$ posterior lens; $\mathrm{O}-\mathrm{O}=$ distance between centres of eyes; $\mathrm{ExGL}=$ external genitalia measured by distance between anterior and posterior edges of external genital sclerite; $\mathrm{EXGLaL}=$ external genital labialae; $\mathrm{AnL}=$ anus; $\mathrm{AnLa}(\mathrm{n})=$ number of anal labialae.

a pair of sensillary setae. Sensillary setae of posterior sensillary area similar to sensillary setae of anterior area, albeit slightly longer (Fig. 2). Double eyes on both sides of crista metopica, behind its mid-level. Lenses on an oval sclerite (Fig. 3).

Opisthosoma: dorsal opisthosomal setae (Fig. 4) similar to each other, slightly asymmetric, longer at the posterior part of the body, with short tooth-like structure at the base. The seta divided into 2 branches (rods), one of them straight, and the other slightly angled. Due to this, the seta resembles a tuning fork. Both rods covered with hairs (Fig. 5). Ventral setae in the posterior part of the body resemble dorsal setae, but ventral ones are slightly longer and thinner in the mid-level (Figs. 6-7).

Genital opening with 2 almost bare genital setae (Fig. 8). Sclerotized anus with 4-5 setae, which resemble ventral setae located in this part of opisthosoma (Fig. 9).

Legs. Typical, proportional, slim. Legs I and IV of similar length, while legs II and III shorter. Normal setulose setae present on all leg segments. Solenidia on tarsi numerous. Cylindrical vestigialae on tibia I, genu I, and genu II (Fig. 10). On tarsus I, smaller famulus, dome-like, rounded on top.

Distribution in Finland (from original label, according to Grid $27^{0}$ system): "668:22 Nauvo, Sandö; beach (Lathyrus japonicum, Thymus sp., Elymus sp. dec. reed); 1.06.1992; P.T. Lehtinen".

Distribution in Poland: see GABRYś (2000). 


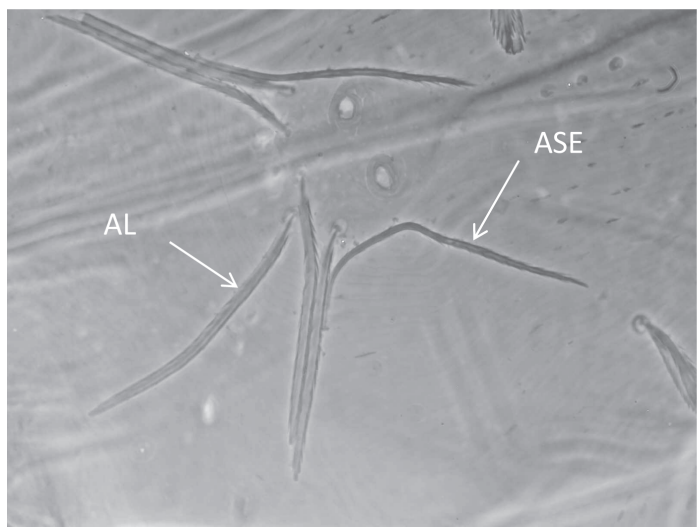

Fig. 1. Kamertonia polonica (deutonymph) - crista metopica - anterior sensillary area.

Not to scale. $\mathrm{AL}=$ nonsensillary seta; $\mathrm{ASE}=$ anterior sensillary seta

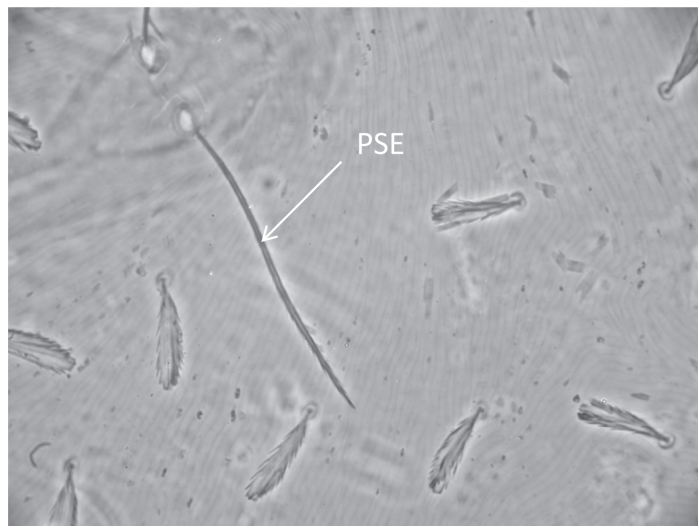

Fig. 2. Kamertonia polonica (deutonymph) - crista metopica - posterior sensillary area. Not to scale. PSE $=$ posterior sensillary seta

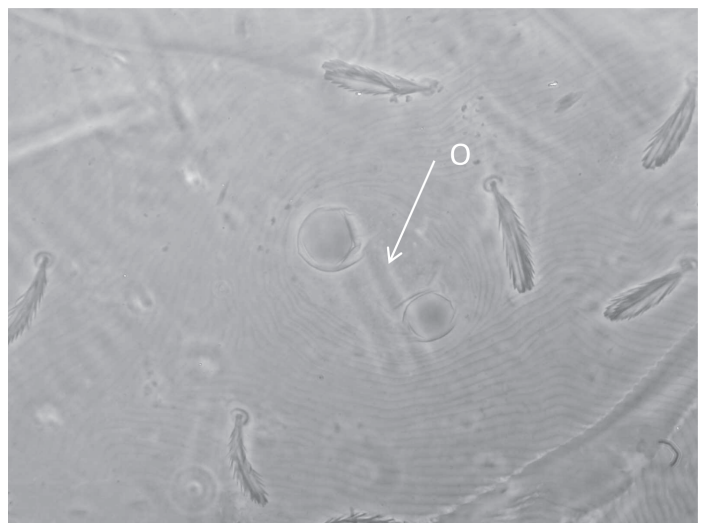

Fig. 3. Kamertonia polonica (deutonymph) - double eye. Not to scale. $\mathrm{O}=$ double eye 


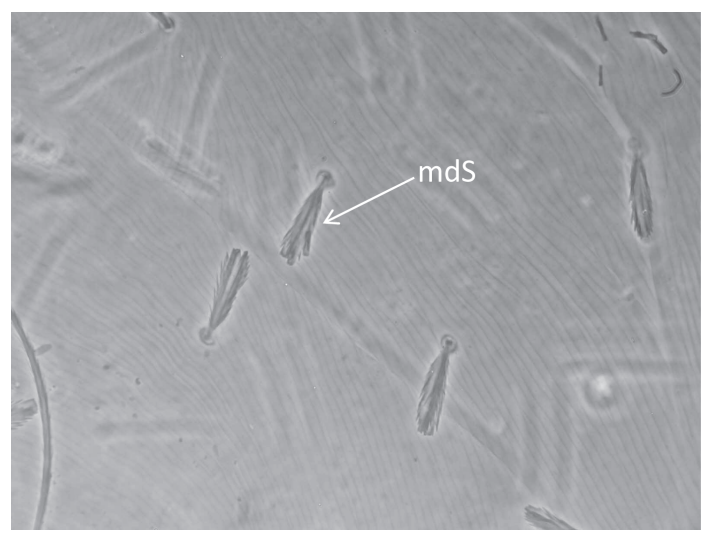

Fig. 4. Kamertonia polonica (deutonymph) - middorsal setae. Not to scale. $\mathrm{mdS}=$ middorsal seta

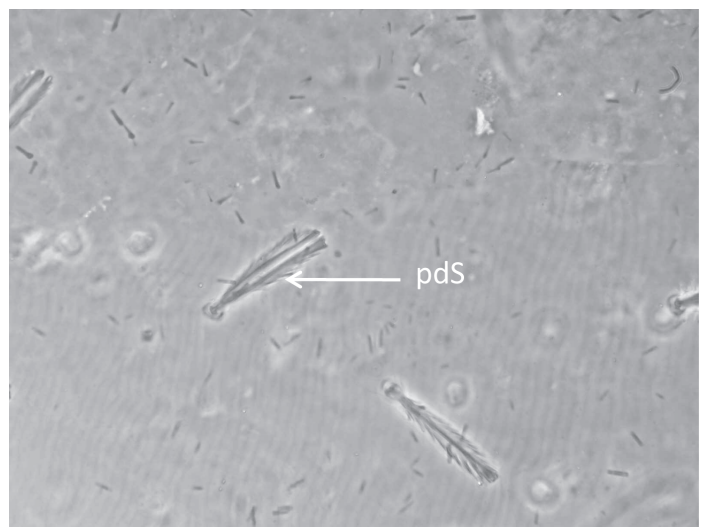

Fig. 5. Kamertonia polonica (deutonymph) - postdorsal setae. Not to scale. $\mathrm{pdS}=$ postdorsal seta

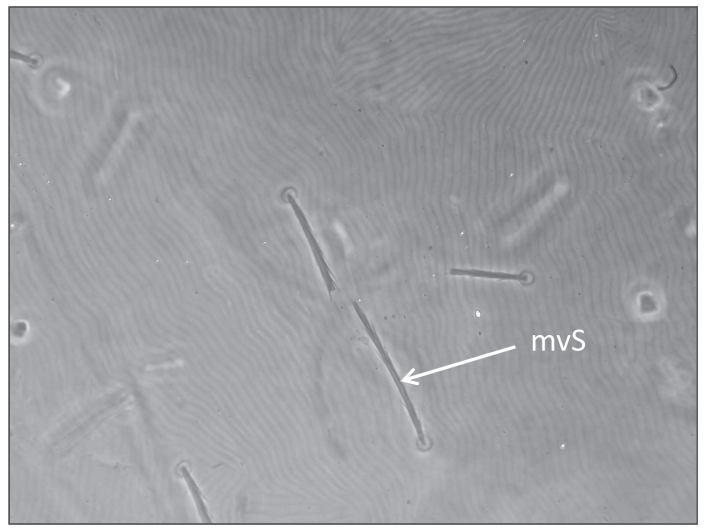

Fig. 6. Kamertonia polonica (deutonymph) - midventral setae. Not to scale. $\mathrm{mvS}=$ midventral seta 


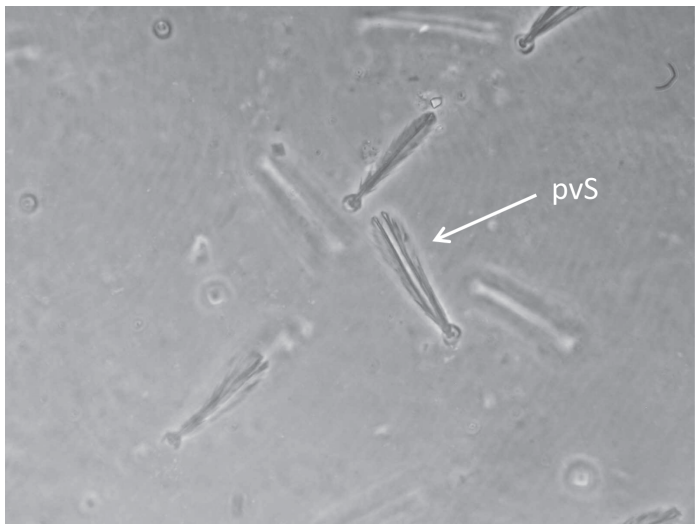

Fig. 7. Kamertonia polonica (deutonymph) - postventral setae. Not to scale. pvS $=$ postventral seta

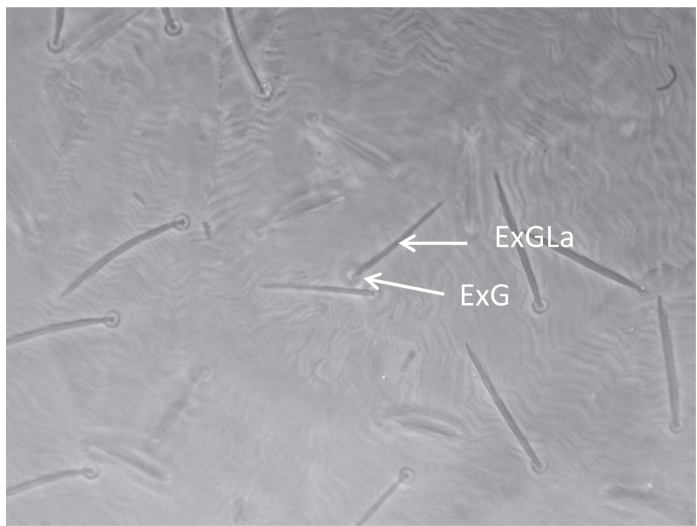

Fig. 8. Kamertonia polonica (deutonymph) - genital region.

Not to scale. $\mathrm{ExG}=$ external genital region; $\mathrm{ExGLa}=$ genital labiala

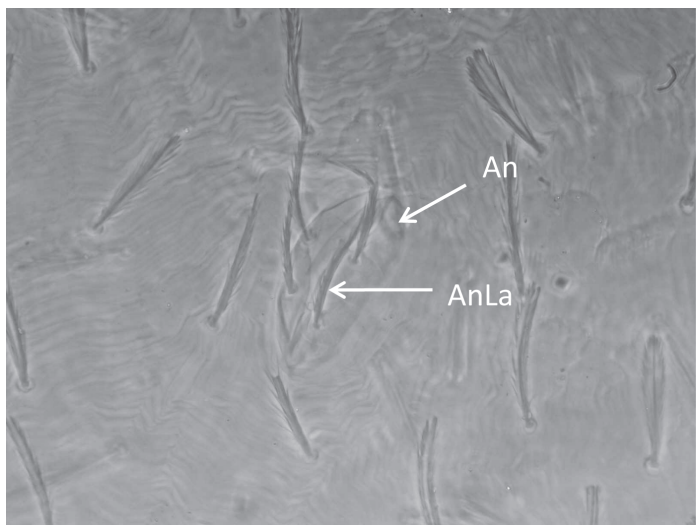

Fig. 9. Kamertonia polonica (deutonymph) - anal region. Not to scale. $\mathrm{An}=$ anus; $\mathrm{AnLa}=$ anal labiala 


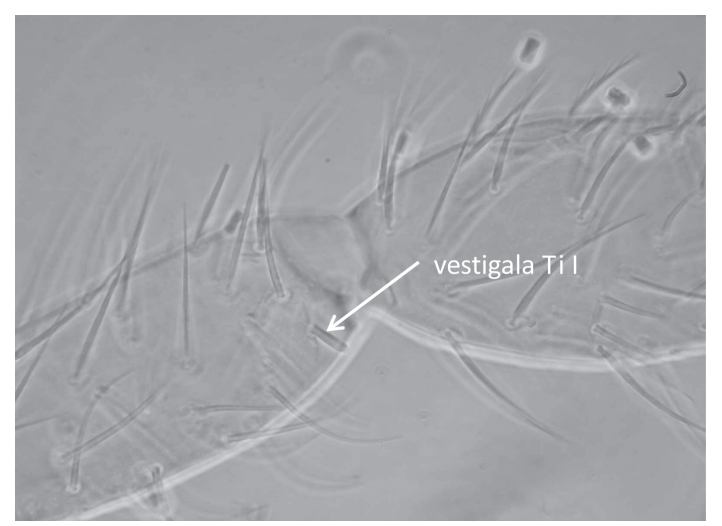

Fig. 10. Kamertonia polonica (deutonymph) - Tibia I - vestigala.

Not to scale. Ti I = Tibia I

Table 2. Palp measurements of Kamertonia polonica deutonymphs from Finland

\begin{tabular}{cccccc}
\hline Character & $\begin{array}{c}\text { No. } \\
\text { of specimens }\end{array}$ & $\begin{array}{c}\text { Mean } \\
(\mu \mathrm{m})\end{array}$ & $\begin{array}{c}\text { Minimum } \\
(\mu \mathrm{m})\end{array}$ & $\begin{array}{c}\text { Maximum } \\
(\mu \mathrm{m})\end{array}$ & $\begin{array}{c}\text { SD } \\
(\mu \mathrm{m})\end{array}$ \\
\hline PaFeW & 6 & 65.5 & 62.0 & 69.4 & 2.80 \\
PaGeW & 6 & 40.0 & 39.0 & 42.2 & 1.11 \\
PaTiW & 6 & 29.2 & 27.3 & 29.8 & 1.01 \\
PaTaW & 6 & 19.1 & 17.4 & 19.8 & 1.10 \\
PaTaL & 6 & 36.9 & 34.7 & 38.0 & 1.13 \\
PaTrL & 6 & 43.4 & 39.7 & 47.1 & 3.03 \\
PaFeL & 6 & 81.4 & 76.9 & 84.3 & 3.32 \\
PaGeL & 6 & 40.1 & 37.2 & 44.6 & 2.86 \\
PaTiL & 6 & 35.9 & 34.6 & 37.2 & 1.39 \\
PaTiClL & 6 & 24.8 & 24.7 & 24.8 & 0.04 \\
L(sum)Pa & 6 & 225.5 & 213.3 & 233.1 & 7.07 \\
\hline
\end{tabular}

$\mathrm{SD}=$ standard deviation; $\mathrm{PaFeW}=$ palpal femur width; $\mathrm{PaGeW}=$ palpal genu width; $\mathrm{PaTiW}=$ palpal tibia width; $\mathrm{PaTaW}=$ palpal tarsus width; $\mathrm{PaTaL}=$ palpal tarsus length; $\mathrm{PaTrL}=$ palpal trochanter length; $\mathrm{PaFeL}=$ palpal femur length; $\mathrm{PaGeL}=$ palpal genu length; $\mathrm{PaTiL}=$ palpal tibia length; $\mathrm{PaTiClL}=$ palpaltibial claw $(=$ odontus) length; $\mathrm{Pa}=$ palp 
Table 3. Leg measurements of Kamertonia polonica deutonymphs from Finland

\begin{tabular}{|c|c|c|c|c|c|}
\hline Character & $\begin{array}{c}\text { No. } \\
\text { of specimens }\end{array}$ & $\begin{array}{l}\text { Mean } \\
(\mu \mathrm{m})\end{array}$ & $\begin{array}{l}\text { Minimum } \\
(\mu \mathrm{m})\end{array}$ & $\underset{(\mu \mathrm{m})}{\operatorname{Maximum}}$ & $\begin{array}{c}\mathrm{SD} \\
(\mu \mathrm{m})\end{array}$ \\
\hline $\mathrm{Cx} I$ & 6 & 114.9 & 106.6 & 121.5 & 5.79 \\
\hline $\operatorname{Tr} I$ & 6 & 38.9 & 37.2 & 39.7 & 1.29 \\
\hline $\mathrm{bFe} I$ & 6 & 67.8 & 62.0 & 71.9 & 3.71 \\
\hline $\mathrm{tFe} I$ & 6 & 133.1 & 119.0 & 141.4 & 8.71 \\
\hline Ge I & 6 & 143.8 & 133.9 & 148.8 & 5.20 \\
\hline Ti I & 6 & 139.7 & 126.5 & 143.8 & 6.58 \\
\hline Ta I & 6 & 90.1 & 86.8 & 94.2 & 3.00 \\
\hline Ta I(H) & 6 & 50.0 & 49.6 & 52.1 & 1.02 \\
\hline L(sum)I & 6 & 728.3 & 674.5 & 744.1 & 26.67 \\
\hline Cx II & 6 & 109.5 & 89.3 & 138.9 & 21.69 \\
\hline Tr II & 6 & 34.3 & 32.2 & 37.2 & 1.88 \\
\hline $\mathrm{bFe}$ II & 6 & 44.3 & 39.7 & 47.1 & 2.88 \\
\hline $\mathrm{tFe} I I$ & 6 & 86.4 & 81.8 & 91.8 & 4.00 \\
\hline Ge II & 6 & 95.0 & 86.8 & 99.2 & 4.34 \\
\hline Ti II & 6 & 106.6 & 101.7 & 111.6 & 4.13 \\
\hline Ta II & 6 & 62.4 & 57.0 & 64.5 & 2.92 \\
\hline Ta II(H) & 6 & 34.7 & 32.2 & 37.2 & 1.58 \\
\hline L(sum)II & 6 & 538.5 & 500.8 & 575.4 & 29.38 \\
\hline CX III & 6 & 37.2 & 34.7 & 44.6 & 3.83 \\
\hline Tr III & 6 & 48.35 & 47.1 & 49.6 & 1.37 \\
\hline bFe III & 6 & 101.3 & 99.2 & 106.6 & 2.88 \\
\hline $\mathrm{tFe}$ III & 6 & 107.5 & 101.7 & 119.0 & 6.18 \\
\hline Ge III & 6 & 64.1 & 62.0 & 67.0 & 2.46 \\
\hline Ti III & 6 & 31.8 & 29.8 & 34.7 & 1.84 \\
\hline Ta III & 6 & 560.9 & 543.1 & 582.8 & 15.64 \\
\hline Ta III(H) & 6 & 101.3 & 91.8 & 114.1 & 7.25 \\
\hline L(sum)III & 6 & 560.9 & 543.1 & 582.8 & 15.64 \\
\hline Cx IV & 6 & 101.3 & 91.8 & 114.1 & 7.25 \\
\hline Tr IV & 6 & 40.1 & 39.7 & 42.2 & 1.02 \\
\hline $\mathrm{bFe} I V$ & 6 & 56.2 & 54.6 & 59.5 & 1.99 \\
\hline tFe IV & 6 & 127.3 & 119.0 & 133.9 & 6.01 \\
\hline Ge IV & 6 & 133.1 & 124.0 & 146.3 & 8.54 \\
\hline Ti IV & 6 & 163.7 & 161.2 & 171.1 & 3.83 \\
\hline Ta IV & 6 & 76.4 & 69.4 & 81.8 & 5.30 \\
\hline Ta IV(H) & 6 & 30.6 & 29.8 & 32.2 & 1.24 \\
\hline L(sum)IV & 6 & 698.1 & 672.1 & 729.1 & 24.14 \\
\hline IP & 6 & 2525.8 & 2390.5 & 2621.5 & 80.40 \\
\hline
\end{tabular}

$\mathrm{SD}=$ standard deviation; $\mathrm{I}$ = first pair of legs; II = second pair of legs; III = third pair of legs; IV = fourth pair of legs; $\mathrm{Cx}=$ coxa; $\mathrm{Tr}=$ trochanter; $\mathrm{bFe}=$ basifemur; $\mathrm{tFe}=$ telofemur; $\mathrm{Ge}=$ genu; $\mathrm{Ti}=$ tibia; $\mathrm{Ta}=$ tarsus; $\mathrm{H}=$ height; $\mathrm{L}=$ length; $\mathrm{IP}=$ index pedibus (= sum of lengths of legs I-IV, including coxae). 


\section{DISCUSSION}

Kamertonia polonica is an exceptionally rare species of Erythraeidae (GABRYŚ 2000). Therefore, its finding at the Finnish coast of Baltic Sea seems highly interesting (GABRYŚ et al. 2009). The similar character of the biotope of the Polish and Finnish localities - sandy dunes and sandy beach - suggests a trans-Baltic distribution of the species. The rarity of $K$. polonica made the studies of its life cycle and, in consequence, the description and correlation of all active instars (i.e., larvae, deutonymphs, and adults) almost impossible. Nevertheless, the structural characters of the Finnish deutonymphs show irrefutably that they represent the same species as the females described originally from Poland by GABRYŚ (2000). The identical structure of crista metopica (Figs. 1, 2), opisthosomal setae (Figs. 4-7), and vestigial seta (vestigiala) on tibia I (Fig. 10) support this view. The differences between the deutonymphs and adults concern meristic and metric characters (Tables 1-3), as in the remaining taxa of terrestrial Parasitengona.

Acknowledgements: We would like to thank Dr. P.T. Lehtinen (Turku, Finland) for providing us with access to the Finnish mite collection, which made this study possible.

\section{REFERENCES}

GABRYŚ G. 1992. Notes on the morphological terminology of Erythraeidae (Acari: Actinedida: Parasitengona). Genus 2: 357-361.

Gabryś G. 1999. The world genera of Microtrombidiidae (Acari, Actinedida, Trombidioidea). Monographs of the Upper Silesian Museum 2: 1-361.

GABRYŚ G. 2000. Kamertonia polonica gen. and sp. nov. from Poland with a key to the world genera of "conalae-less" Erythraeinae (Acari: Actinedida: Erythraeidae). Ann. Zool. 50: 57-63.

Gabryś G., Roland E., Mąkol J., Lehtinen P. T. 2009. Erythraeoidea (Acari: Prostigmata: Parasitengona) of Finland - state of knowledge and new data. Zesz. Nauk. UP Wroc., Biol. Hod. Zwierz. 58: 21-28.

Krantz G. W. 1978. A manual of acarology. Oregon State Univ. Book Stores, Corvallis:1-509.

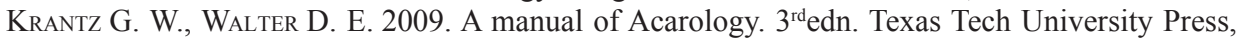
Lubbock, TX, USA: 1-807.

MĄKol J. 2005. Trombidiidae (Acari: Actinotrichida: Trombidioidea) of Poland. Fauna Poloniae, 1, NS: $1-259$.

Roland E. 2008. Erythraeoidea (Acari: Prostigmata: Parasitengona) Finlandii. PhD Thesis [manuscript]: $1-319$.

Southсотт R. V. 1961. Studies on the systematics and biology of the Erythraeoidea (Acarina), with a critical revision of the genera and subfamilies. Aust. J. Zool. 9: 367-610.

Welbourn W. C., Young O. P. 1987. New genus and species of Erythraeinae (Acari: Erythraeidae) from Mississippi with key to the genera of North American Erythraeidae. Ann. Entomol. Soc. Am. 80: 230-242. 